\title{
Ordenação e resolução temporal em cantores profissionais e amadores afinados e desafinados****
}

\author{
Ordering and temporal resolution in professional singers and in well \\ tuned and out of tune amateur singers
}

\author{
Cintia Ishii* \\ Priscila Midori Arashiro** \\ Liliane Desgualdo Pereira***
}

*Fonoaudióloga. Pesquisadora Voluntária do Departamento de Fonoaudiologia da Universidade Federal de São Paulo. Endereço para Correspondência: Rua Munduba, 97 Brooklin - São Paulo - SP - CEP 04567-080

(cintia_ishii@yahoo.com.br).

**Fonoaudióloga. Pesquisadora Voluntária do Departamento de Fonoaudiologia da Universidade Federal de São Paulo.

***Fonoaudióloga. Doutora em Ciências pela Universidade Federal de São Paulo - Escola Paulista de Medicina. Professor Adjunto do Curso de Fonoaudiologia da Universidade Federal de São Paulo - Escola Paulista de Medicina.

****Trabalho Realizado na Universidade Federal de São Paulo Escola Paulista de Medicina.

Artigo de Pesquisa

Artigo Submetido a Avaliação por Pares

Conflito de Interesse: não

Recebido em: 29.07.2005

Revisado em: 08.09.2005; 03.04.2006; 22.05.2006; 29.08.2006.

Aceito para Publicação em 26.10.2006.

\begin{abstract}
Background: temporal ordering and temporal resolution. Aim: to compare the performance of professional singers with that of well tuned and out of tune amateur singers in the pitch pattern test (PPT) and in the Random Gap Detection Test (RGDT). Method: participants were 78 individuals, male and female, with ages ranging from 18 to 55 years. All of the participants were singers with normal hearing - previously assessed using pure tone and speech audiometry - and had no language, speech, voice or hearing complaints. Each individual answered a questionnaire concerning, among other subjects, perception about own voice when singing, number of years of professional singing, difficulties when singing new songs and number of years of music study. For the objective assessment the PPT and the RGDT were used in order to investigate temporal ordering and temporal resolution respectively. Results: regarding the RGDT, there was no statistically significant difference between the groups and variables. As for the PPT, it was observed that professional singers presented a better performance, with statistic significance, when compared to well tuned amateur singers and these a better performance when compared to out of tune amateur singers. The performance in the PPT was related to specialized training and study of music theory. Conclusion: the RGDT did not prove to be a sensitive test to distinguish professional and amateur singers. On the other hand, the PPT did. The performance in the PPT reflects the number of years of specialized auditory training and music theory study.
\end{abstract}

Key Words: Hearing; Auditory Tests; Auditory Perception; Speech; Language and Hearing Sciences.

\section{Resumo}

Tema: ordenação e resolução temporal. Objetivo: comparar o desempenho de cantores que recebem orientação profissional, cantores amadores independentes e cantores amadores desafinados nos testes de padrão de freqüência sonora e teste de detecção de gap (Random Gap Detection Test). Método: participaram 78 indivíduos, de ambos os gêneros, com idade variando entre 18 e 55 anos. Foram incluídos cantores com audição normal, comprovada por meio de exame audiológico e com ausência de queixas de linguagem, fala, voz ou audição. Cada indivíduo respondeu a um questionário fornecendo várias informações, entre elas, a sua própria percepção auditiva sobre sua voz cantada; o tempo de canto com orientação profissional, dificuldade para cantar novas músicas e o de estudo de teoria musical. Para a avaliação foram utilizados o Teste de Padrão de Freqüência Sonora (TPF) e o Teste de Detecção de Gap Randomizado (RGDT) a fim de avaliar as habilidades de ordenação temporal e a resolução temporal respectivamente. Resultados: no que se refere ao teste de detecção de gap randomizado (RGDT) não houve diferença estatisticamente significante entre as respostas por grupo e por variável. Em relação ao desempenho do TPF foi observado que o grupo que recebe orientação profissional possui desempenho superior e estatisticamente significante em relação ao grupo de amadores independentes e estes melhor do que o grupo de amadores desafinados. O desempenho no teste de padrão de freqüência teve relação com o treinamento especializado e com o estudo de teoria musical. Conclusão: o teste de detecção de gap (RGDT) não se mostrou sensível para distinguir cantores com orientação profissional de amadores, ao contrário do teste de padrão de freqüência sonora. O desempenho no teste de padrão de freqüência reflete o maior treinamento auditivo especializado e de estudo de teoria musical.

Palavras-Chave: Audição; Testes Auditivos; Percepção Auditiva; Fonoaudiologia.

Referenciar este material como:

ISHII, C.; ARASHIRO, P. M.; PEREIRA, L. D. Ordering and temporal resolution in professional and amateur singers regarding tune. (original title: Ordenação $\checkmark$ e resolução temporal em cantores profissionais e amadores afinados e desafinados). Pró-Fono Revista de Atualização Científica, Barueri (SP), v. 18, n. 3, p.285-292, set.-dez. 2006 


\section{Introduction}

To have a good reproduction of what we listen it is necessary to hear well and it involves not just a good sound detection but also efficient sensorial processing of auditory information by the central auditory system.

According to ASHA (1996) auditory processing depends on the auditory system's mechanisms and on the behavioral phenomena that accompanies it: sound localization and lateralization; auditory discrimination; auditory patterns recognition; temporal aspects of hearing including temporal resolution, temporal masking, temporal integration, temporal ordering; performance with competitive acoustic signs; and performance with degraded acoustic signs.

It is known that to produce intelligible speech there is a great dependency on the abilities to process the acoustic specter paradigm and the speaker's speech prosody. And this appreciation constitutes language and hearing forming basis (Pereira et al., 2002).

Auditory processing evaluation involves the listener's abilities to identify, discriminate and identify segmental and supra-segmental speech aspects; and this ability is directly associated to auditory temporal aspects (Cassab e Zorzetto, 2002). Shinn (2003) states that temporal processing is involved in most of the auditory processing abilities because most of the auditory information are, at lest partly, influenced by time.

To recognize and identify auditory patterns several auditory and perceptual processes are involved, as the correct perception of the variations and temporal ordering of the acoustic elements (Gil et al. 2000). The temporal resolution may be defined as the ability to detect time gaps between sound stimuli or to detect the shortest time necessary to an individual discriminate between two audible sounds (Phillips et al, 2000; Shinn, 2003).

The most important tests that evaluate temporal processing include the test of frequency pattern, the test of duration pattern and the test of betweenstimuli-time gap detection, among others (Au e Lovegrove, 2001; Baran e Musiek, 2001; Neijenhuis et al, 2001). Emanuel (2002) observed in his research that more than $60 \%$ of the examiners of the area use the frequency pattern test and rarely use the tests of duration pattern and gap detection.

Considering that singers must be good listeners it is believed that auditory processing information must be functionally adequate in those considered well tuned and it is proposed the hypothesis that some untuned would be atypical listeners. According to Heresniak (2004) an individual that do not follow musical melody through pitch may present some cognitive impairment. Sobreira (2003) states that vocal tuning is influenced by acoustic and cultural points of view and although it may follow evaluation criteria it is necessary to consider contextual and cultural factors. According to the same author tuning involves the reproductions of isolated notes and understanding the musical structure they are in. The untuning in singing may be defined as the inability in vocal reproducing the melodic line and the gaps between notes, what makes it different from the suggested model. The possible causes of un-tuning may be related to musical perception or to the vocal domain or to their co-occurrence.

This way, knowing the temporal processing of well tuned singers may help in understanding the fact that untuning may be a consequence of the singers own atypical hearing.

This way the objective of this study is to compare the performance of singers that had professional orientation, well tuned amateur singers and untuned amateur singers on sound frequency pattern tests and on the Random Gap Detection Test.

\section{Method}

This study was approved by the institution's Research Ethic Committee (CEP- Unifesp/EPM) with protocol number 0530/04.

Each participant was informed about the aim of the study and it was started after determining the inclusion criteria meeting, obtaining agreement and consent form signature. All ethical procedures determined by resolution 196/96 (Ministério da Saúde, 1996) about research with human beings were met.

To the realization of this study 78 individuals were selected, of both genders, 65 female and 13 male, between 18 and 55 years.

As inclusion criteria participants had normal hearing confirmed by audiologic exam (tonal audiometry, speech audiometry and acoustic imitance measures) and no complaints related to disorders of voice, language, speech and hearing.

Each participant filled a questionnaire identifying his/her singing voice, difficulties in learning to sing new songs, if had any kind of professional orientation about singing (with regent, singing teacher or speech pathologist) and for how long, if studied musical theory and also for how long. 
It wasn't realized specific vocal tuning tests and the following criteria was used to determine the group division: singers that received professional orientation by a singing teacher, regent or speech pathologist (singing classes, chorus participation) and that sang for at least four years were categorized as professional singers. In this group, if there was no complaint about the acoustic perception about the singing voice, the individuals were classified as well tuned professional singers (CPA).

Those who sang as a hobby (karaoke, videoke and others) but without professional orientation were categorized as amateur singers (CA). Besides, the amateur singers were subcategorized in two groups based in the model used by Sobreira (2003) adapted from Samuel Forcucci, published in 1975 and on the answers provided to the questionnaire. Those who didn't present complaints about their singing voice and that are able to sing satisfactorily with or without vocal or instrumental backing were considered well tuned and considered independent amateur singers (CAI). Those with complaints involving their singing voices and of not being able to adjust their tuning to the partner and therefore sing with distortions were classified as untuned amateur singers (CAD).

Latter tests of auditory processing were applied to evaluate the abilities of temporal ordering and temporal resolution.

Temporal ordering was evaluated by the Frequency Pattern Test (TPF) with answer of linguistic labeling due to its sensibility to persons with auditory training. This test was proposed by Musiek and colleagues (1990) and consists on the presentation of low tones $(880 \mathrm{~Hz})$ and high tones $(1122 \mathrm{~Hz})$ with 500 milliseconds duration and a time gap of 300 milliseconds between stimuli.

Temporal resolution was evaluated by the Random Gap Detection Test (RGDT) proposed by Robert Keith (2000), a revised version of the Auditory Fusion Test by McCrosky and Keith (1996). RGDT consists of the presentation of several pairs of pure tones on the frequencies of $500 \mathrm{~Hz}$, $1000 \mathrm{~Hz}, 2000 \mathrm{~Hz}$ and $4000 \mathrm{~Hz}$ with randomly varying time gap between stimuli between 2 to 40 milliseconds. This procedure allows the determination of the individual's temporal acuity threshold, that is, the shortest time (in milliseconds - ms) necessary to perceive the presence of two pure tones.

The evaluations were conducted in the Hearing Disorders Ambulatory of the Universidade Federal of Sao Paulo - Escola Paulista de Medicina. The audiologic exams (tonal audiometry and speech audiometry) were done in an acoustic cabin with an audiometer AC33 and the acoustic imitance measures were obtained by an imitanciometer AZ 7. The auditory processing tests were also realized in an acoustically treated cabin with stimuli presented through earphones by a laser disk recording played on a Toshiba CD player with 40 seconds anti-chock coupled to a GSI clinical audiometer with two channels of Welch Allyn brand.

The statistical analysis used non-parametric statistical tests with significance level of 0.05 (5\%) as the Wilcoxon test to paired data, the KuskalWallis and the Mann-Whitney tests to independent data; and to the descriptive analysis the Confidence Interval and Pearson's Correlation. The statistical confidence of $95 \%$ in used to the analysis.

\section{Results}

Table 1 presents the distribution of individuals according to the pre-determined groups: professional singer (CPA), independent amateur singer (CAI) or untuned amateur singer (CAD) and according to the gender. Table 2 shows the distributions of each group according to the questionnaire variables.

In Table 3 are presented the lower and higher thresholds, in correct answers percentage to each group on the TPH test. Table 4 shows the $p$-values used to compare the performance of each group on the TPF. Figure 1 presents the mean values of correct answers on the Frequency Pattern Test (TPF) to each group.

Statistically significant differences between groups were detected. Mann Whitney Test, applied after the p-values of groups on TPF determination, showed that CPA presented the larger mean of corrected answers followed by CAI and than by CAD.

When grouping the individuals according to the presence of difficulties to learn to sing new songs the mean percentage of correct answers on TPF observed was $87.5 \%$ and on the group without this difficulty the observed percentage was $89.3 \%$. This difference wasn't statistically significant ( $p$ value $=0.606$ ) on the Mann-Whitney Test.

On the group of individuals that reported musical study there were $96.5 \%$ of right answers while the group that didn't study musical theory presented $82.3 \%$ of correct answers. This difference is statistically significant ( $p$-value < 
0.001). There were no gender-related significant differences on the TPF answers, as presented on Figure 2.

Comparing the performance on the TPF of both ears the Wilcoxon Test resulted in $p$-values of: 0.152 (CAI), 0.868 (CAD) and 0.656 (CPA) indicating that there is no statistically significant difference between the ears on each group.

Table 5 shows the values of the lower and higher thresholds of temporal acuity (in milliseconds) to each group as measured by the Random Gap Detection Test (RGDT). Figure 3 presents the mean values of temporal acuity thresholds. The KruskalWallis Test was used to study the correct answers on the RGDT and didn't identify statistically significant difference between groups and test frequencies of $500 \mathrm{~Hz}, 1000 \mathrm{~Hz}, 2000 \mathrm{~Hz}$ and 4000 $\mathrm{Hz}$ (p-values: respectively 0.775; 0.110; 0.947; and $0.412)$.

The Mann-Whitney test studying the correlations between RGDT performances and the variables: difficulties to learn to sing new songs (mean threshold p-value: 0.541 ) and time of musical theory study (mean threshold $p$-value: 0.532 ) didn't identify any effect. The same statistical test also didn't determine any gender-related significant difference (mean threshold $p$-value 0.641).

TABLE 1. Distribution of the population of singers (C) as professional (P), independent (A) or untuned (D) and of male and female genders.

\begin{tabular}{cccc}
\hline & Female & Male & Total \% \\
\hline CPA & 14 & 1 & $19,2 \%$ \\
\hline CAI & 15 & 8 & $29,5 \%$ \\
\hline CAD & 36 & 4 & $51,3 \%$ \\
\hline Total & 65 & 13 & $100 \%$ \\
\hline
\end{tabular}

TABLE 2. Distribution of complaints of difficulties learning new songs and of musical theory study to each group.

\begin{tabular}{cccccc}
\hline & Difficulty to learn to sing new songs & Musical theory study & Total \\
& Yes & No & Yes & No & 01 \\
\hline CPA & 00 & 15 & 14 & 09 & 31 \\
\hline CAI & 05 & 18 & 09 & 314 \\
\hline CAD & 06 & 34 & 37 & 41 \\
\hline
\end{tabular}


TABLE 3. Correct answers percentage on TPF test lower and higher thresholds to each group.

\begin{tabular}{lccc}
\hline Frequency on groups & Tuned & Independent & Untuned \\
& professionals & amateurs & amateurs \\
\hline Lower threshold & $95.8 \%$ & $90.5 \%$ & $79.8 \%$ \\
\hline Higher threshold & $99.5 \%$ & $95.7 \%$ & $87.7 \%$ \\
\hline
\end{tabular}

TABLE 4. P-values comparing performance between groups on TPF.

\begin{tabular}{ccc}
\hline Frequency on groups & CAI & CAD \\
\hline CAD & $0.001^{*}$ & - \\
\hline CPA & $0.004^{*}$ & $<0,01^{*}$ \\
\hline
\end{tabular}

* p-values on Mann-Whitney Test.

TABLE 5. Loower and higher threshold values of auditory acuity to each group (in milliseconds).

\begin{tabular}{|c|c|c|c|c|c|c|c|c|c|c|c|c|c|c|c|}
\hline \multirow[t]{2}{*}{ Thresh. } & \multicolumn{3}{|c|}{ Mean } & \multicolumn{3}{|c|}{$500 \mathrm{~Hz}$} & \multicolumn{3}{|c|}{$1000 \mathrm{~Hz}$} & \multicolumn{3}{|c|}{$200 \mathrm{~Hz}$} & \multicolumn{3}{|c|}{$4000 \mathrm{~Hz}$} \\
\hline & СРA & CAI & CAD & СРA & CAI & CAD & CPA & CAI & CAD & CPA & CAI & CAD & СРA & CAI & CAD \\
\hline Lower & 5.27 & 4.77 & 5.12 & 4.50 & 4.98 & 4.73 & 4.53 & 3.10 & 3.85 & 5.06 & 5.41 & 5.50 & 4.50 & 4.15 & 5.55 \\
\hline Higher & 8,09 & 6,95 & 9,32 & 8,57 & 7,63 & 9,42 & 9,87 & 4,73 & 7,95 & 8,14 & 9,98 & 8,14 & 8,30 & 6,89 & 11,1 \\
\hline
\end{tabular}


FIGURE 1. Mean values of correct answers percentage on the TPF on the groups independent amateur singers (CAI), untuned amateur singers (CAD) and tuned professional singers (CPA).

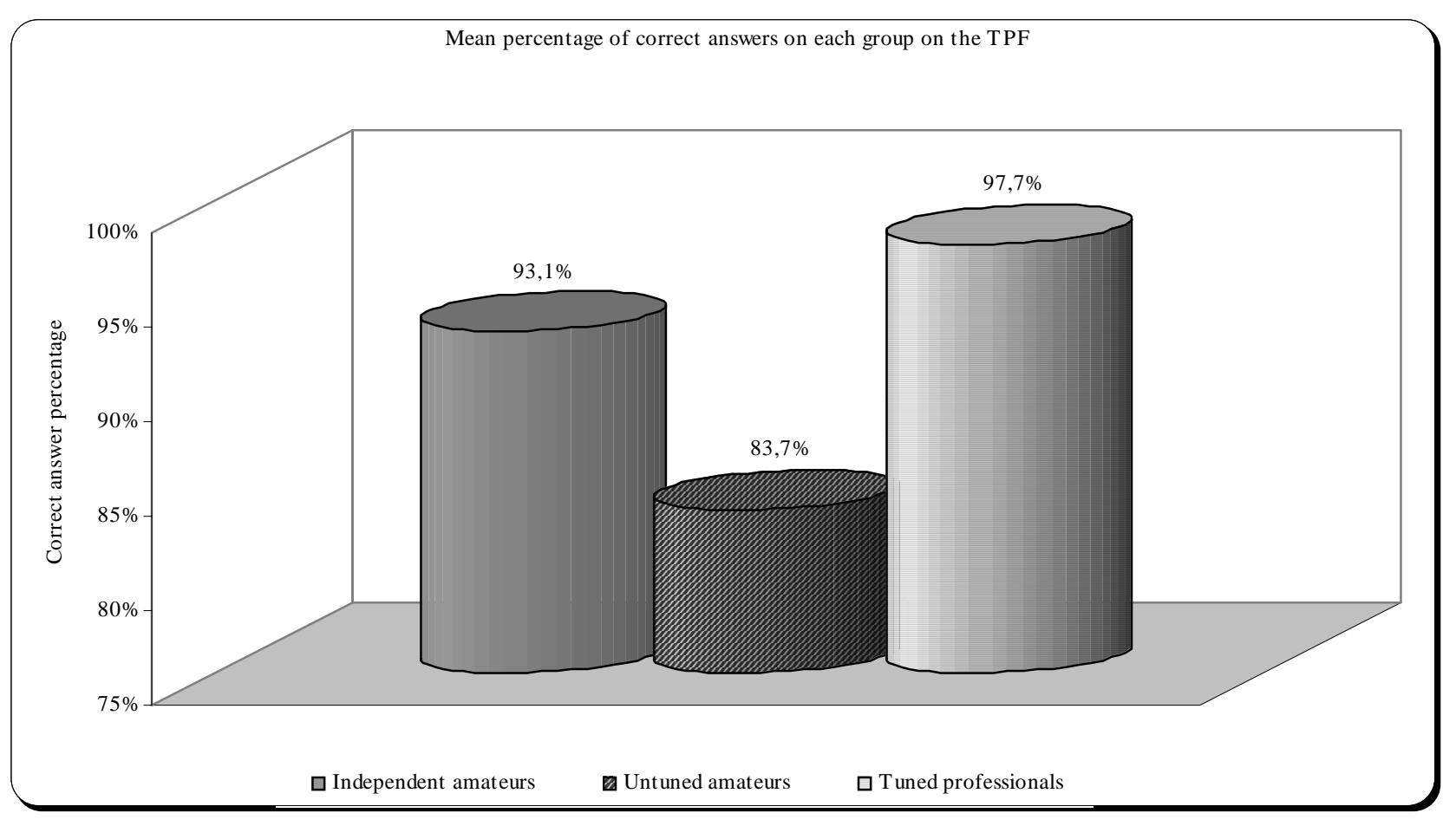

FIGURE 2. Mean percentage of correct anwers to TPF of professional and amateur singers according to the presence or absence of difficulties to sing new songs and musical theory study.

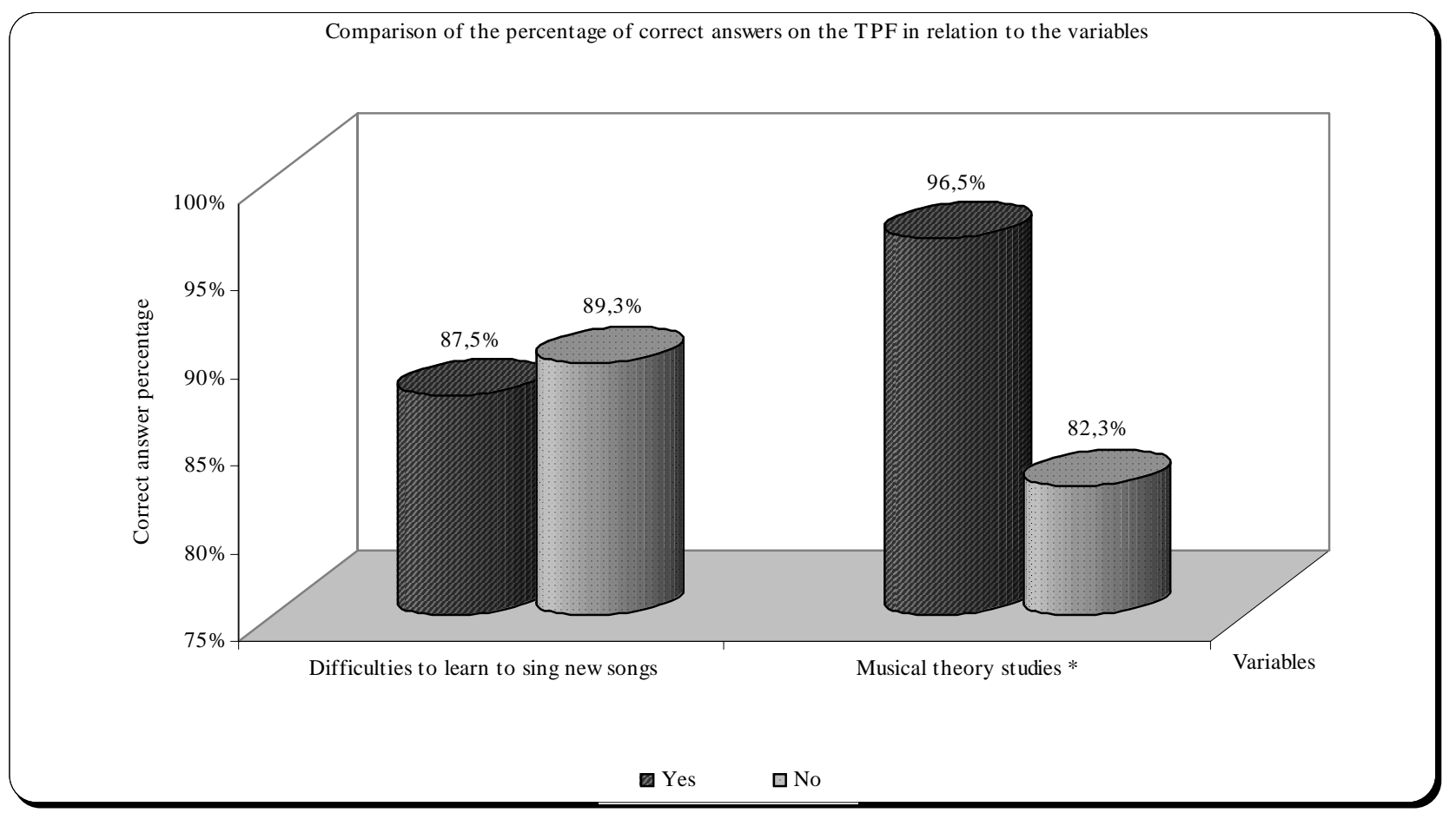


FIGURE 3. Mean values of the temporal acuity thresholds on the RGDT in the groups on the groups of independent amateur singers (CAI), untuned amateur singers (CAD) and tuned professional singers (CPA).

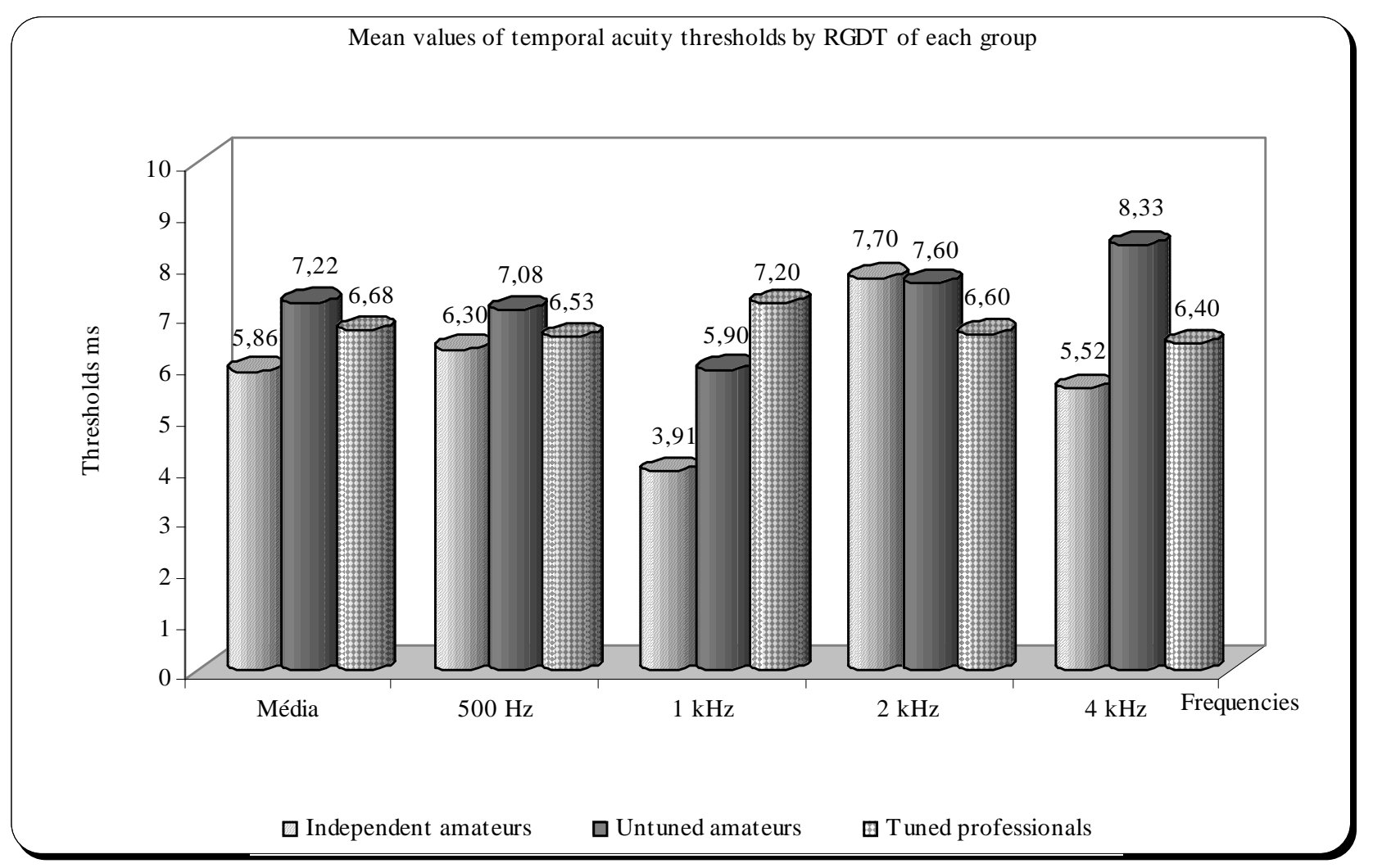

\section{Discussion}

Singers are people that follow musical melodies with harmony with their voices, producing musical notes with exactitude. To do this it some prerequisites are necessary as having good peripheral and central hearing, functionally adequate phonatory system, among others. According to Heresniak (2004) the disorders may be organic, cognitive or functional.

Temporal processing clues are relevant to the speech intelligibility at least in two levels: on the supra-segmental level (prosodic) and on the segmental level (phonemic), according to Scheneide and Pichora-Fuller (2001). On the segmental level the syllable rhythm and speed influence the lexical and syntactic language processing. On the supra-segmental level, clues about duration and gap influence on the phoneme identification. This way, some complaints of difficulties to listen and sing along a melody may not be due to hearing abilities losses, but to troubles in the ability to temporal process acoustic clues. Recent studies relate the temporal processing with language development (Moura et al, 2000; Bailey e Snowling, 2002; Gimenes e Pereira, 2002; Branco-Barreiro, 2003; Costa et al, 2004; Fortes, 2004).

Recognizing the frequency pattern, as measured by TPF tests, has shown no statistically difference between the tested ears (right and left). These results agree with the study described by Musiek (1994) with normal individuals.

The TPF depends on several central auditory processes as the recognition of the whole, interhemispheric transference, linguistic qualification, linguistic data sequencing and memory indices (Musiek et al, 1980, Schochat et al, 2000).

Comparing the performance of each group on the TPF it can be observed that the CPA group presented better performance than the group CAI which, by its turn produced a larger amount of 
right answers than the CAD group. This results graduation may be explained by the musical training that the professional singer had. The auditory training may be conducted to improve the individual's auditory abilities by singing teacher or by other professionals (Heresniak, 2004).

Gil et al (2000), found statistically significant differences on the TPF performances of a group with auditory training and a group without this training, where the group with auditory training presented better performance in recognition tasks. Schochat et al (2002) describe a study with efficient auditory training where the trained abilities are kept after training.

Our findings that show a better performance in individuals with developed musical abilities agree to the ones described by Gil et al (2000).

The study comparing the TPF performance with the questionnaire variables there were statistically significant differences on the item "time of musical theory".

Musiek et al (1980) stated that tonal patterns are recognized as music or melody because they are formed by tones of different frequencies and duration in several temporal sequences. With this, the exposure to musical theory and auditory training are important factors to the analysis and results of performance on frequency pattern recognition tasks. In this study the association between musical education and competence in frequency pattern recognition became evident.

According to Minifie (1973) the ability with temporal resolution is very important to the recognition of speech sounds and changes of duration, pauses and syllable speed providing important clues to comprehension. Studies suggest that temporal resolution may be considered a predictor of learning, reading and righting disorders (Cestnick e Jerger, 2000; Garcia, 2001; Hautus et al, 2003).
The temporal resolution measure was made by the RGDT test, which allows the determination of the temporal acuity threshold. In this study it wasn't observed a statistically significant difference on temporal acuity threshold between the three groups of singers. Also, when comparing the results of these thresholds between the tests frequencies and the questionnaire variables, there were no statistically significant differences either. This way, singing untuning was not associated to a lack of efficiency in temporal resolution or to being a singer or having musical education nor being well-tuned interfered with temporal acuity threshold.

Temporal resolution is a pre-requisite to good performance in speech comprehension and therefore to be a good speaker. As we dealt with individuals without voice, speech, hearing or language complaints our sample has shown to be formed of good speakers with good temporal resolution abilities.

\section{Conclusion}

Auditory abilities of temporal ordering of three sounds is more developed in singers with professional orientation than in amateur singers and the well-tuned singers presented better performance on the TPF than the untuned. This way it was observed that the musical theory study influenced on the performance on temporal ordering.

The temporal acuity threshold is similar in singers, professional or amateur, well-tuned or not. The exposure to music and singing do not influence on temporal resolution ability as measured by the test used in the present study. 


\section{References}

AMERICAN SPEECH LANGUAGE HEARING ASSOCIATION (ASHA). Central auditory processing: current status of research and implications for clinical pratice. Am. J. Audiol., Rockville, v. 5, n. 2, p. 41-54, jul. 1996.

AU, A.; LOVEGROVE, B. Temporal processing ability in above average and average readers. Percept Psychophys, Austin, v. 63, n. 1, p. 148-155, jan. 2001.

BAILEY, P. J.; SNOWLING, M. J. Auditory processing and the development of language and literacy. Br. Med. Bull, London, v. 63, p. 135-146, 2002.

BARAN, J. A.; MUSIEK, F. E. Avaliação comportamental do sistema nervoso auditivo central. In: MUSIEK, F. E.; RINTELMANN, W. F. Perspectivas atuais em avaliação auditiva. São Paulo: Manole, 2001. cap. 13, p. 371-409.

BRANCO-BARREIRO, F. C. A. Estudo do processamento auditivo temporal em alunos de escola pública com e sem dificuldade de leitura. 2003. 133 f. Tese (Doutorado em Neurociência e Comportamento) - Faculdade de Medicina, Universidade de São Paulo, São Paulo.

CASSAB, T. V.; ZORZETTO, N. L. Teste da fusão auditivarevisado (AFT-R) em crianças com fissura labiopalatina. Acta AWHO, São Paulo, v. 21, n. 3 e n. 4, p. 25-32, jul.dez. 2002.

CESTNICK, L.; JERGER, J. Auditory temporal processing and lexical/nonlexical reading in developmental dyslexics. J. Am. Acad. Audiol., Hamilton, v. 11, n. 9, p. 501-513, set. 2000.

COSTA, L. P.; PEREIRA, L. D.; SANTOS, M. F. C. Teste de fusão auditiva em crianças escolares. Pró-Fono R. Atual. Cient.,Barueri (SP), v. 16, n. 2, p. 187-196, maio-ago. 2004.

EMANUEL, D. The auditory processing battery: survey of common practices. J. Am. Acad. Audiol., Hamilton, v. 13, n. 2, p. 93-119, feb. 2002.

FORCUCCI, S. L. Help for inaccurate singers. Mus. Educ. J., Washington, v. 62, n. 2, p. 57-61, 1975. Apud: SOBREIRA, S. G. Desafinação vocal. Rio de Janeiro: Musimed, 2003. cap. 1, p. 15-54.

FORTES, A. B. Resolução temporal: análise em préescolares nascidos a termo e pré-termo. 2004. 104 f. Tese (Mestrado em Distúrbios da Comunicação Humana) Universidade Federal de São Paulo, São Paulo.

GARCIA, V. L. Processamento auditivo em crianças com e sem distúrbios de aprendizagem. 2001. 298 f. Tese (Doutorado em Distúrbios da Comunicação Humana) Universidade Federal de São Paulo, São Paulo.

GIL, D.; ALMEIDA, C. C. DE; PHEE, A. M.; ARTONI, A. L.; PELLOGIA, C. C.; ANTUNES, F.; PEREIRA, L. D. Efeito do treinamento auditivo para a percepção musical nos testes de padrão de freqüência e duração. Acta Awho, São Paulo, v. 19, n. 2, p. 64-67, abr.-jun. 2000.

GIMENES, V. D.; PEREIRA, L. D. Teste de padrão tonal de duração e freqüências sonoras e habilidades grafofônicas. Pró-Fono R. Atual. Cient., Barueri (SP), v. 14, n. 2, p. 187-196, 2004.

HAUTUS, M. J.; SETCHELL, G. J.; WALDIE, K. E.; KIRK, I. J. Age-related improvements in auditory temporal resolution in reading-impaired children. Dyslexia, Chichester, v. 9, n. 1, p. 37-45, feb. 2003.
HERESNIAK, M. The Care and training of adult bluebirds: teaching the singing impaired. J. Singing, v. 61, n. 1, p. 925, set.-oct. 2004.

KEITH, R. W. Random gap detection test. Missouri (USA): Auditec of Saint Louis, 2000.

McCROSKEY, R. L.; KEITH, R. W. AFT-R: auditory fusion test-revised. Saint Louis: Auditec, 1996.

MINIFIE, F. Speech acoustics. In: MINIFIE, T.; HIXON, T.; WILLIAMS, F. Normal aspects of speech, hearing and language. Englewoods Cliffs (NJ): Prentice-Hall, 1973. chap. 7.

MOURA, D. R. V.; FENIMAN, M. R.; LAURIS, J. R. P. Teste de fusão auditiva: revisado em crianças com distúrbio de leitura e escrita. J. Bras. Fonoaudiol., v. 3, p. 38-43, 2000.

MUSIEK, F. E. Frequency (pitch) and duration patterns tests. J. Am. Acad. Audiol., Hamilton, v. 5, n. 4, p. 265268, jul. 1994.

MUSIEK, F. E.; BARAN, J. A.; PINHEIRO, M. L. Duration pattern recognition in normal subjects and patients with cerebral and cochlear lesions. Audiology, Basil, v. 29, n. 6, p. 304-313, 1990.

MUSIEK, F. E.; PINHEIRO, M. L.; WILSON, D. Auditory pattern perception in split-brain patients. Arch. Otolaryngol., Chicago, v. 106, n. 10, p. 601-602, oct. 1980.

NEIJENHUIS, K. A. M.; STOLLMAN, M. H. P.; SNIK, A. F. M.; BROEK, P. V. D. Development of a central test battery for adults. Audiology, Basil, v. 40, n. 2, p. 69-77, mar.-apr. 2001.

PEREIRA, L. D.; NAVAS, A. L. G. P.; SANTOS, M. T. M. Processamento auditivo: uma abordagem de associação entre a audição e a linguagem. In: SANTOS, M. T. M.; NAVAS, A. L. G. P. Distúrbios de leitura e escrita: teoria e prática. 1. ed. São Paulo: Manole, 2002. cap. 2, p. 27-74.

PHILLIPS, S. L.; GORDON-SALANT, S.; FITZGIBBONS, P. J.; YENI-KOMSHIAN, G. Frequency and temporal resolution in elderly listeners with god and poor word recognition. J. Speech Lang. Hear. Res., Rockville, v. 43, n. 1, p. 217-218, feb. 2000.

SCHOCHAT, E.; RABELO, C. M.; SANFINS, M. D. Processamento auditivo central: testes tonais de padrão de freqüência e de duração em indivíduos normais de 7 a 16 anos de idade. Pró-Fono R. Atual. Cient., Carapicuíba (SP), v. 12, n. 2, p. 1-7, set. 2000.

SCHOCHAT, E.; CARVALHO, L. Z.; MEGALE, R. L. Treinamento auditivo: avaliação da manutenção das habilidades. Pró-Fono R. Atual. Cient., Barueri (SP), v. 14, n. 1, p. 93-98, abr. 2002.

SHINN, J. B. Temporal processing: the basics. Hear. J., Pathways, v. 56, n. 7, p. 52, jul. 2003.

SCHENEIDE, B. A.; PICHORA-FULLER, K. Age-related changes in temporal processing: implications for speech perception. Semin. Hear., v. 22, n. 3, p. 227-239, 2001.

SOBREIRA, S. G. Desafinação Vocal. Rio de Janeiro: Musimed, 2003. cap. 1, p. 15-54. 